\title{
TAXONOMIC NOTES ON DREPANOLEJEUNEA PLEIODICTYA (MARCHANTIOPHYTA, LEJEUNEACEAE), A LITTLE-KNOWN ASIATIC SPECIES
}

\author{
Janejaree InUthai ${ }^{1}$, Rui-Liang Zhu \& Sahut Chantanaorrapint
}

\begin{abstract}
Drepanolejeunea pleiodictya Herzog (Lejeuneaceae), a rare and poorly known species from Java and Malaysia, was newly discovered in tropical montane forest in southern Thailand. It is distinguished by the ventral margin of the leaf lobe being usually irregularly dentate with one large tooth, the apex of the lobule having a straight or slightly curved tooth, ocelli 3-4(-5) seriate in the leaf lobe separated by $2-5$ ordinary leaf cells, and gynoecia usually with a single pycnolejeuneoid innovation. This species is described and illustrated in detail, and its diagnostic characters and geographical distribution are briefly discussed.
\end{abstract}

Key words: Drepanolejeunea, habitat, Indonesia, Lejeuneaceae, Peninsular Malaysia, Thailand

Janejaree Inuthai \& Sahut Chantanaorrapint, PSU Herbarium, Department of Biology, Faculty of Science, Prince of Songkla University, Hat Yai, Songkhla 90112, Thailand; e-mail: j.inuthai@gmail.com

Rui-Liang Zhu, Department of Biology, School of Life Sciences, East China Normal University, 3663 Zhong Shan North Road, Shanghai 200062, China; e-mail: rlzhu@bio.ecnu.edu.cn

\section{INTRODUCTION}

The genus Drepanolejeunea (Spruce) Schiffn. was first described by Spruce (1884) as a subgenus of Lejeunea Lib. and was subsequently raised to generic rank by Schiffner (1893). The genus has been classified in the separate subtribe Drepanolejeuneinae Gradst. together with Vitalianthus R. M. Schust. \& Giancotti (Gradstein 2013). The genus is characterized by yellowish green plant color, deeply bilobed underleaves with lobes frequently widely spreading, the presence of ocelli in the leaf lobes, leaf lobules having 1-2 apical teeth (a single, strongly curved one in most species) and a proximal hyaline papilla, female bracts connate with the bracteole on both sides, the pycnolejeuneoid leaf sequence of the gynoecial innovation, inflated perianths usually with various projections near the apex, and vegetative reproduction by cladia or caducous leaves. Drepanolejeunea is common and widespread in the Tropics but has never been monographed on a worldwide basis. There are numerous floristic

\footnotetext{
1 Corresponding author
}

reports of Drepanolejeunea species from tropical Asia, for example from China (Zhu \& So 2001; Wang et al. 2011), India (Dey et al. 2013), Malaysia (Chuah-Petiot 2011; Lee et al. 2013), Java (Söderström et al. 2010), Singapore (Piippo et al. 2002), Borneo and the Philippines (Tan \& Engel 1990), and Thailand (Lai et al. 2008; He et al. 2012; Inuthai et al. 2014). Nevertheless, the taxonomy of the genus in tropical Asia remains incompletely known.

As part of a revision of the genus Drepanolejeunea in Thailand and Peninsular Malaysia, numerous Drepanolejeunea specimens were collected in these areas and examined. One of the most interesting species in our material from Thailand is Drepanolejeunea pleiodictya Herzog. This species was first described by Herzog (1934) based on a collection made by Verdoorn in 1930 in Java, Indonesia, and was subsequently recorded by Tixier (1980) from Gunong Jasar, Cameron Highlands, Malaysia. Our collection is the third record of the species and the first one from Thailand. The following description and illustrations 
of D. pleiodictya are based on the holotype kept in Herbarium Haussknecht (JE) and on the collections from Thailand.

\section{DESCRIPTION}

\section{Drepanolejeunea pleiodictya Herzog}

Fig. 1

Ann. Bryol. 7: 89-90, Fig. 32-33. 1934.

TyPe: INDONESIA. JAVA: 'Res. Priangan, in mm. Papandayan, G. Djaja, in decl. occ., in silv. primigen, 1700-1900 m', August 1930, Verdoorn s.n. (HOLOTYPE: JE!).

Plants bright green to yellowish when fresh, $0.5-0.8 \mathrm{~cm}$ long. Shoots $0.3-0.5 \mathrm{~mm}$ wide, usually unbranched or slightly branched, occasionally irregularly pinnate, branches of Lejeunea type, leaf sequence of vegetative branches lejeuneoid. Stem in transverse section with 7 cortical cells and 3 medullary cells; ventral merophyte 2 cells wide. Rhizoids present at base of underleaves, few to numerous, tufted, usually hyaline, rhizoid disc absent. Leaves contiguous, diverging from stem at $45^{\circ}-60^{\circ}$ angle; leaf lobe elliptic, oblanceolate to spathulate, not falcate, $0.45-0.75 \mathrm{~mm}$ long, 0.20-0.35 mm wide, apex acute, plane, ventral margin usually irregularly dentate with one large tooth, dorsal margin entire to slightly dentate; leaf lobules elliptic to oblong, 2/5-1/2 as long as lobes, lateral free margin bordered by $5-6$ elongate rectangular marginal cells, apex usually constricted, with unicellular, straight or slightly curved tooth, 22.5-29.0 × 10-15 $\mu \mathrm{m}$, keel arched, almost smooth to weakly crenulate, hyaline papilla suborbicular to oblong, $10-12 \times 8-10 \mu \mathrm{m}$, situated at proximal base of tooth. Cells of leaf lobe with thin walls and very small trigones, intermediate thickenings indistinct or small; cells at margin of leaf lobe subquadrate, $22-30 \times 8-12 \mu \mathrm{m}$, in middle subquadrate, $20-40 \times 16-18 \mu \mathrm{m}$, near base similar to median cells in shape but slightly smaller, 30-35 $\times 10-16 \mu \mathrm{m}$. Cuticle smooth. Ocelli 3-4(-5) seriate in leaf lobe separated by $2-5$ ordinary leaf cells, apical ocelli 20-35 × 20-25 $\mu \mathrm{m}$, median ocelli $30-45 \times 22-30 \mu \mathrm{m}$, basal ocelli $42-48 \times$ 25-28 $\mu \mathrm{m}$. Underleaves distant, 3 times as wide as stem, bilobed to near base, lobes uniseriate with 3-4 cells long, spreading at $65^{\circ}-90^{\circ}$ angle with stem. Dioicous. Androecia on short or long lateral branches, bracts in 3-7 pairs, imbricate, concave and inflated, obliquely spreading, lobes $0.22-0.24 \mathrm{~mm}$ long, 0.09-0.10 mm wide, apex acute, margin slightly dentate, lobule slightly shorter than or almost as long as lobe, keel strongly arched; bracteole 1, present at basal portion of androecial shoot. Gynoecia terminal on short branches, usually with single pycnolejeuneoid innovation; bracts ovate-oblong, $0.35-0.45 \mathrm{~mm}$ long, $0.12-0.15 \mathrm{~mm}$ wide, lobe elliptic-oblong, with scattered ocelli, apex acute or acuminate, margin slightly dentate, lobule oblong, $2 / 3$ as long as bract lobe, apex acute, keel dentate; bracteole connate with bracts on both sides at base, obovate-oblong, margin usually dentate, apex bilobed to $1 / 3-2 / 5$ its length. Perianths about $1 / 2-2 / 3$ exserted, obtriangular to obovate, $c a 0.80 \mathrm{~mm}$ long, $0.30-0.40 \mathrm{~mm}$ wide at middle, inflated, with 5 wings, wings decurrent equal in size, lacinate to crenulate with 1-2 coarse teeth at apex; surface of perianth smooth to slightly mamillose, with scattered ocelli; beak 1-2 cells long. Sporophyte common. Seta in transverse section with 4 inner and 12 outer cells, articulate, with 8 articulations. Capsule black, spherical, $175-180 \mu \mathrm{m}$ in diameter, splitting $\pm 2 / 3$ its length into four erect valves after dehiscence, capsule valves 240-280 $\mu \mathrm{m}$ long and 145-160 $\mu \mathrm{m}$ wide, hyaline. Elaters 36 per capsule; marginal elaters 22 per capsule, each valve contains 4 or 3 upper and 2 lower marginal elaters; upper marginal elaters 157.5-162.5 $\mu \mathrm{m}$ long, 12.5-20.0 $\mu \mathrm{m}$ wide, hyaline, with rudimentary spiral band, tip attached to valve, free base truncate; lower marginal elaters $c a 100 \mu \mathrm{m}$ long, $c a 10 \mu \mathrm{m}$ wide, attached to valve by both end, hyaline; inner or additional elaters 14 per capsule, either 3 or 4 per valve, 125-150 $\mu \mathrm{m}$ long, ca $6.2 \mu \mathrm{m}$ wide, hyaline, end narrowly tapered to expanded. Spores green, irregular oblong or elongate-rectangular in shape, $50-85 \times 32.5-35.0 \mu \mathrm{m}$; spore surface covered with small granules and with 3-5 rosettes on the surface. Asexual reproduction by cladia, originating on normal branches, more or less attached to substrate, rhizoid disc present, cells of rhizoid disc large. 

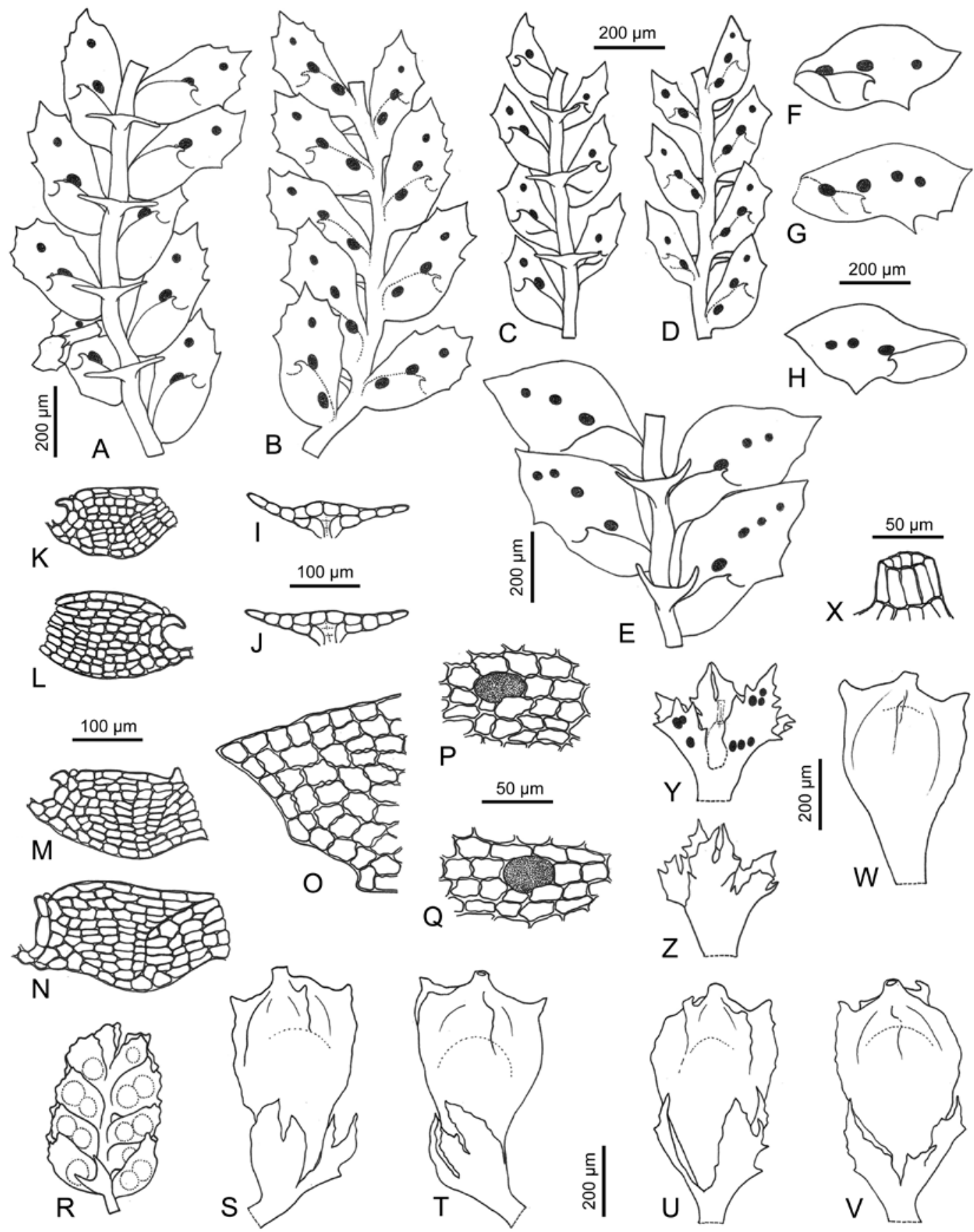

Fig. 1. Drepanolejeunea pleiodictya Herzog. A-E - portions of plants, ventral and dorsal views; F-H - lateral leaves; I \& J - underleaves; K-N - leaf lobules; O - apical cells of leaf lobe; P - medial cells of leaf lobe; Q - basal cells of leaf lobe; $\mathrm{R}$ - androecium, ventral view; S-V - gynoecium, ventral and dorsal views; $\mathrm{W}$ - perianth, lateral view; $\mathrm{X}$ - beak of perianth; Y \& Z - female bracts and bracteole. A, B, G-I and K-R drawn from Chantanaorrapint \& Inuthai 1634D, C-F, J and S-X drawn from Chantanaorrapint \& Inuthai $1621 \mathrm{~B}$, and $\mathrm{Y}-\mathrm{Z}$ drawn from Chantanaorrapint \& Inuthai $2878 \mathrm{D}$. 
Habitat. Drepanolejeunea pleiodictya occurs on living leaves in tropical montane forest above $1000 \mathrm{~m}$, and was found growing associated with D. actinogyna J. Inuthai et al., D. dactylophora (Nees et al.) Schiffn., D. levicornua Steph., D. pentadactyla (Mont.) Steph. and D. tenera K. I. Goebel, among others.

Distribution. Indonesia (Java), Peninsular Malaysia and new to Thailand.

SPecimens examined: THAILAND. NaKhon Si Thammarat Province: Ron Phibun District, Khao Ramrome Mountain, montane forest, $08^{\circ} 23^{\prime} 882^{\prime \prime} \mathrm{N}$, 99 $80^{\prime} 562^{\prime \prime} \mathrm{E}$, ca 1000 m, 20 Sept. 2012, Chantanaorrapint \& Inuthai 1620C, 1621B, 1634D (PSU); 25 Sept. 2013, Chantanaorrapint \& Inuthai 2878D (PSU).

TaXonomic notes. Drepanolejeunea pleiodictya is characterized by ( $i$ ) the leaf lobe obliquely spreading, elliptic, oblanceolate to spathulate, not falcate, ventral margin usually irregularly dentate with one large tooth, (ii) the apex of the lobule with a straight or slightly curved tooth, 22.5-29.0 $\times 10-15 \mu \mathrm{m}$, (iii) ocelli 3-4(-5) seriate in the leaf lobe and separated by $2-5$ ordinary leaf cells, and (iv) gynoecia usually with a single pycnolejeuneoid innovation. Interestingly, the wings of the perianth in the type material from Indonesia (only 2 perianths seen) are lacinate, while being crenulate with 1-2 coarse teeth at the apex in the material from Thailand. We consider this difference to be part of the variation of $D$. pleiodictya. Similar variation of the perianth wings can be found in other species such as D. longicornua (Herzog) Mizut., D. pentadactyla, D. thwaitesiana var. zhengii R. L. Zhu and D. yunnanensis (P. C. Chen) Grolle \& R. L. Zhu.

Drepanolejeunea pleiodictya can be confused with D. moluccensis Herzog from the Moluccas and Bali (Herzog 1934). They share many characters such as small plant size, yellowish green plant color, seriate ocelli, male bracteole restricted to the base of the androecium, and lacinate perianths. However, D. moluccensis differs by having only one large tooth on the leaf lobe (ventral margin usually irregularly dentate in D. pleiodictya), and by the presence of only two ocelli in the leaf lobe, separated by one ordinary leaf cell [ocelli 3-4(-5) seriate in the leaf lobe, separated by $2-5$ ordinary leaf cells in $D$. pleiodictya $]$.

Drepanolejeunea pleiodictya was formerly known only from Java and Peninsular Malaysia, and is new for Thailand. The new record represents the northernmost locality of this species. This species could easily be overlooked in botanical explorations because of its small size. In Thailand it is known only from Khao Ramrome Mountain but it might have a wider distribution and may occur in other areas of southern Thailand as well. The recent discovery of a new species and new records of bryophytes from southern Thailand (Chantanaorrapint \& Pócs 2014; Chantanaorrapint et al. 2014; Inuthai et al. 2014; Lee et al. 2014) indicates that this is an important region for bryophyte diversity investigation, and that further new species records may be expected from unexplored areas in this part of the country, especially in the Nakhon Si Thammarat mountain range.

ACKNOWLEDGEMENTS. We thank the curators and staff of G, HSNU, JE, and PSU for kindly allowing us to study specimens, including types, and Professor S. Robbert Gradstein (Paris) and Dr. Gaik Ee Lee (Selangor) for helpful remarks and suggestions on the manuscript. Financial support by the Graduate School, Prince of Songkla University, Hat Yai, Songkhla, Thailand, Science Achievement Scholarship of Thailand (SAST), and the National Natural Science Foundation of China (no. 31170190) is gratefully acknowledged.

\section{REFERENCES}

Chantanaorrapint S. \& Pócs T. 2014. Southern Thailand bryophytes I, with description of Cololejeunea ramromensis. Biodiversity, Biogeography and Nature Conservation in Wallacea and New Guinea 2: 113-122.

Chantanaorrapint S., Peng T. \& Zhu R.-L. 2014. Reappraisal of Dendroceros cucullatus (Dendrocerotaceae, Anthocerotophyta). Phytotaxa 167(1): 145-149.

Chuah-Petiot M. S. 2011. A checklist of Hepaticae and Anthocerotae of Malaysia. Polish Bot. J. 56(1): 1-44.

Dey M., Singh D. \& Singh D. K. 2013. The genus Drepanolejeunea (Marchantiophyta: Lejeuneaceae) in India with a note on three new additions from Eastern Himalaya. Trop. Bryol. 35: 14-25.

GRADSTEIN S. R. 2013. A classification of Lejeuneaceae based on molecular and morphological evidence. Phytotaxa 100: 6-20. 
He Q. \& Zhu R.-L., Chantanaorrapint S., KornoChalert S. \& Printarakul N. 2012. Drepanolejeunea laciniata (Lejeuneaceae), a new species from northern Thailand. Cryptog. Bryol. 33: 291-298.

Herzog T. 1934. Studien über Drepanolejeunea II. Ann. Bryol. 7: 57-94.

InUthai J., Zhu R.-L. \& Chantanaorrapint S. 2014. Drepanolejeunea actinogyna (Lejeuneaceae), a new species from southern Thailand. Bryologist 117(2):165-169.

Lai M.-J., Zhu R.-L. \& Chantanaorrapint S. 2008. Liverworts and hornworts of Thailand: an updated checklist and bryofloristic accounts. Ann. Bot. Fenn. 45: 321-341.

Lee G. E., Gradstein S. R., Söderström L. \& Latiff A. 2013. Catalogue of the Lejeuneaceae of Malaysia. Malayan Nat. J. 65(2-3): 81-129.

Lee G. E., Pócs T., Chantanaorrapint S., Damanuri A. \& LATIFF A. 2014. An account of the genus Lejeunea (Marchantiophyta: Lejeuneaceae) in Thailand, including seven newly recorded species. Cryptog. Bryol. 35(3): 247-259.

Piippo S., He X.-L., Juslén A., Tan B. C., Murphy D. H. \& Pócs T. 2002. Hepatic and hornwort flora of Singapore. Ann. Bot. Fenn. 39: 101-127.
SCHIFFner V. 1893. Hepaticae (Lebermoose). In: A. Engler \& K. Prantl, Die natürlichen Pflanzenfamilien 1(3): 3-141. Engelmann, Leipzig.

SöDerström L., Gradstein S. R. \& Hagborg A. 2010. Checklist of the hornworts and liverworts of Java. Phytotaxa 9: 53-149.

Spruce R. 1884. Hepaticae of the Amazon and Andes of Peru and Ecuador. Trans. \& Proc. Bot. Soc. Edinburgh 15: $1-308$.

TAN B. C. \& ENGEL J. J. 1990. A preliminary study on the affinities of Philippine, Bornean and New Guinean hepatics. Trop. Bryol. 2: 265-272.

TIXIER P. 1980. Contribution to the bryological knowledge of Malaysia III. Cameron Highlands, mosses and epiphyllous liverworts. Nova Hedwigia 32: 377-392.

WANG J., LAI M.-J. \& ZHU R.-L. 2011. Liverworts and hornworts of Taiwan: an updated checklist and floristic accounts. Ann. Bot. Fenn. 48: 369-395.

ZHU R.-L. \& So M. L. 2001. Epiphyllous liverworts of China. Nova Hedwigia Beih. 121: 1-418. 